\title{
The TAWOCK conceptual model at content knowledge for professional teaching in vocational education
}

\author{
Zainal Arifin', Muhammad Nurtanto ${ }^{2}$, Warju Warju ${ }^{3}$, Rabiman Rabiman ${ }^{4}$, Nur Kholifah ${ }^{5}$ \\ ${ }^{1}$ Department of Automotive Engineering Education, Yogyakarta State University, Indonesia \\ ${ }^{2}$ Department of Mechanical Engineering Education, Universitas Sultan Ageng Tirtayasa, Indonesia \\ ${ }^{3}$ Department of Mechanical Engineering, Universitas Negeri Surabaya, Indonesia \\ ${ }^{4}$ Department of Mechanical Engineering Education, Universitas Sarjanawiyata Tamansiswa, Indonesia \\ ${ }^{5}$ Department of Culinary and Fashion Education, Yogyakarta State University, Indonesia
}

\section{Article Info}

Article history:

Received Mar 3, 2020

Revised Jun 20, 2020

Accepted Jul 18, 2020

\section{Keywords:}

Andragogy knowledge

TAWOCK model

TPACK model

Vocational education

Work knowledge

\begin{abstract}
Now days, the integration of technology in the concept of learning is the trend in global education. The conceptual framework model is a general reference, and the only concept is Technology, Pedagogy, and Content Knowledge (TPACK). However, vocational education has knowledge of specific content, so adjusting conceptual models in professional learning is important to learn and offer. The purpose of this study is to evaluate the concept of TPACK into the concept of vocational education to improve the professionalism of vocational teachers in content knowledge. The author discusses the knowledge structure of vocational fields that are built based on work, content, technology, and the suitability of the learning approach. Based on the results of the article found a new construction in building knowledge in the field of vocational education with special expertise characteristics and shifting pedagogical concepts towards andragogy in learning concept. The results of the analysis recommend the TPACK concept transformed into the Technology, Andragogy, Work, and Content Knowledge (TAWOCK) concept in vocational learning.
\end{abstract}

This is an open access article under the CC BY-SA license.

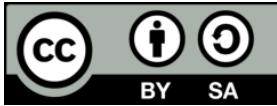

\section{Corresponding Author:}

Muhammad Nurtanto,

Department of Mechanical Engineering Education,

Faculty of Teacher Training and Education,

Universitas Sultan Ageng Tirtayasa,

Cipocok Jaya, Kota Serang, Banten 42124, Indonesia.

Email: mnurtanto23@untirta.ac.id

\section{INTRODUCTION}

Teachers as instructors and learners have the most considerable influence in building students' experiences and understanding [1, 2]. Researchers and experts identified this concept with the term Pedagogical Knowledge Content (PCK) which provides an understanding of teaching not only the delivery of knowledge and students are not limited to the receipt of information, but rather its application. PCK is known as a professional teacher who is prepared differently from the teacher's material knowledge. PCK is considered an integrated and accumulated expertise in teacher teaching practices [3]. The concept of PCK is very diverse and experiences, conceptual differences, but knowledge in PCK is inseparable from aspects of subject matter, strategic instructional representations, student learning and conceptions, general pedagogy, curriculum and media, context, purpose, and assessment [4-10]. However, the conceptual framework underwent transformation according to 21 st century developments with technology integration. This makes PCK develop in the form of TPACK [11-13]. Despite the developments, PCK and TPACK are still relevant 
for use by researchers. If observed in the knowledge of PCK content [14-17] and TPACK [18, 19] are identical with science; while research with the same characteristics is still limited in its application in the field of vocational education. Therefore, researchers consider the concept of a framework with vocational characteristics adapted from the TPACK concept to be offered as new model literature.

Professional vocational teachers adjust to change and are oriented towards the ability of students to masterwork skills (learning outcomes). Trilling and Fadel, conveyed the concept of learning outcomes that must be achieved into three elements, namely life and career skills, learning and innovation skills, and information, media, and technology skills [20]. All elements of this skill are directed at the concept of delivering learning or a conceptual model framework. This is a strong reason that the teacher is declared as a professional in the process of pouring the concept of knowledge. Through a clear concept, the aim of vocational education cannot be separated from its trajectory, namely as a solution in reducing unemployment [21, 22], thus giving birth to a new economy [23, 24]. All study discussions in the scope of technology including the TPACK concept were packaged by Mishara \& Koehler [12]. Of course, the learning objectives of general education $[25,26]$ and vocational education have different approaches.

Chua and Jamil [27] has implemented TPACK into the TVET program with the consideration of a curriculum that involves many technologies [28] and multidisciplinary [29], so the technology knowledge is needed, namely TPACK. Researchers have a different perspective, where vocational education has specific reasons in certain fields and occupations and the pedagogical learning approach has shifted to andragogy where students have responsibility for their performance. This side is used as an excuse even though the TPACK adaptation is still being raised. The TPACK concept used by researchers does not mean it is not appropriate but will be different if it is adjusted to the field of work and learning approach. This is a strong reason why TPACK requires an evolution in the context of vocational learning.

\section{RESEARCH METHOD}

This study evaluates the concept of knowledge in vocational education that has applied TPACK and limitations in similar research. The knowledge content approach is approached in two points of view, namely works objectives and learning approaches. The literature review is applied to propose a framework for transforming conceptual models according to the characteristics of vocational education as an important reference. In this study the central position as an important element in developing theory and evaluating practical problems. Roel [30] uses a conceptual framework model as a frame of research problems, describing phenomena, and analyzing their structure. The form of conceptual structure framework can the form of a set of constructs in the definition of phenomena and artifacts related to the context of the problem set [30]. The context of the problem is the evaluation of the TPACK framework in the perspective of vocational education needs. The conceptual structure of the evaluation model framework for vocational education is presented in Figure 1.

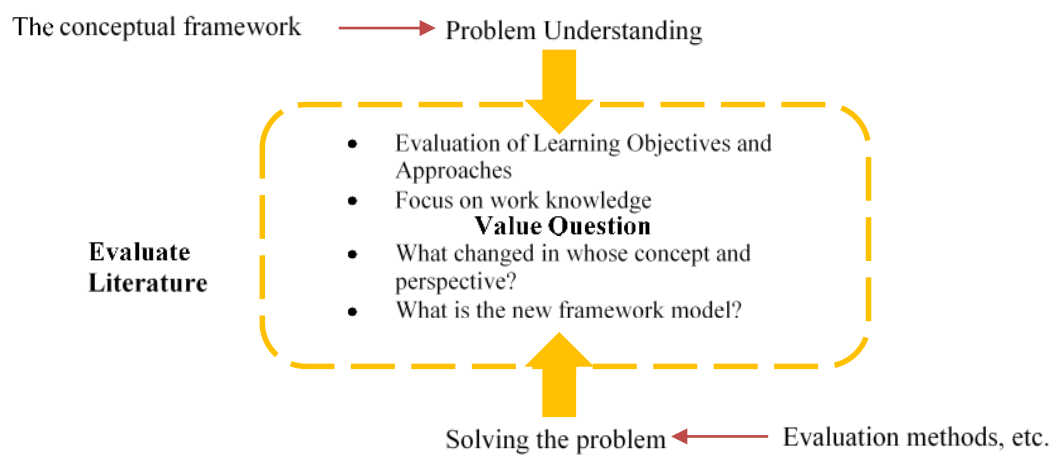

Figure 1. Evaluation of framework model content knowledge for vocational education

\section{RESULTS AND DISCUSSION}

\subsection{Analysis of the concept of content knowledge changes}

The concept of knowledge in learning undergoes rapid change. This research is based on the concept of thinking, namely the philosophy of vocational education that is held. Vocational education relies on meeting individual needs and the necessities of their lives [31]. This opinion is in line with Pavlova that vocational education prepares students to enter the workforce [32, 33]. In meeting needs, students must be 
able to compete and win the competition. The role of the vocational teacher is present in packaging the concept of understanding that matches the conditions of the workplace. Thus the curriculum content is needed in accordance with the context of the work objectives. Vocational education cannot be equated with general education. It is because vocational education is oriented to specific skills in certain occupations [34]. Sudira defines matters relating to the nature of work [35]. This means the nature, aspects, paths and levels of work, careers through the development of different competencies. Researchers found the overall vocational concept, namely education for work.

The TPACK conceptual framework is general, while the needs for vocational education between fields have different achievements. That is, TPACK lacks discipline when applied in the vocational field. In the TPACK domain, the emphasis is on technological knowledge, pedagogical knowledge and content knowledge, which is integrated into the context of learning. However, work goals or expertise does not emerge if this concept is applied in vocational education. So, with a philosophical approach to vocational education, the concept of work can be used as reference material. Also, TPACK uses a pedagogical approach while vocational education is adult education [36]. This means that the concept of the pedagogical learning approach is seen as not suitable to be applied to vocational students. Sudira [35] offers a concept of learning with a Tri-Gogy approach, namely (1) pedagogy, (2) andragogy; and (3) heutagogy. Pedagogical learning approaches are teacher-centered, but andragogy and heutagogy prioritize student activity. This consideration reinforces the need for researchers to transform learning approaches in the context of vocational education. The pedagogical approach is less efficient in student freedom to develop adults and independence. While, illustrates that the challenge of the 21 st century is to describe learning that leads to the maturity of learning. The level of learning approaches for adults and independence is presented in Figure 2.

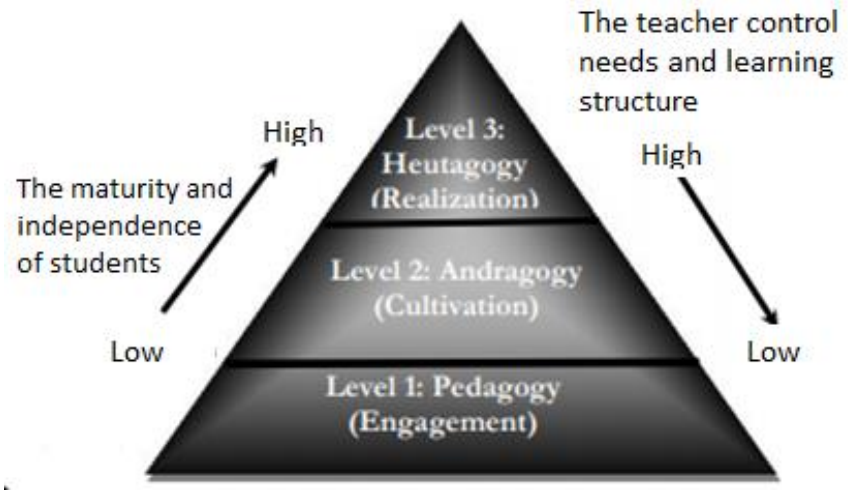

Figure 2. Level of learning approaches between pedagogy, andragogy, heutagogy [37]

Thus the concept of TPACK has evolved in the knowledge of work and changed the knowledge of pedagogy with knowledge of andragogy. So the elements of renewal include Technology, Andragogy, Work, and Content Knowledge or called the new term TAWOCK. Table 1 shows the distribution of knowledge in the field of science in the vocational field.

Table 1. Content knowledge change

\begin{tabular}{ccc}
\hline Knowledge Concept & Science of CK & Value in Vocational CK \\
\hline Content & $\sqrt{ }$ & $\sqrt{ }$ \\
Work & - & $\sqrt{ }$ \\
Pedagogy & $\sqrt{ }$ & - \\
Andragogy & - & $\sqrt{ }$ \\
Technology & $\sqrt{ }$ & $\sqrt{ }$ \\
\hline Source: adapted from Mishra and Koehler [12], adjusted.
\end{tabular}

\subsection{TAWOCK conceptual framework for vocational education}

The results of the research that were built produce four dominant needs in teaching knowledge in vocational education. Construction includes knowledge of content, knowledge of work, knowledge of technology and knowledge of learning approaches (andragogy). The dominant of the four terms, researchers 
refer to as TAWOCK (Technology-Andragogy-Work-Content Knowledge). The domain is determined with the following understanding:

a. The Technology Knowledge (TK) is how to use technology as a tool to support learning. Technology is the ease of learning in theory and practice [38].

b. The Andragogy Knowledge (AK) is how teachers teach competent-based work-oriented learning material. Learning is used with an adult approach and forms of independence such as PBL, PjBL, constructivism, collaboration [39].

c. The Content Knowledge (CK) is an important point to be learned according to the expert competence unit [40].

d. The Work Knowledge (WK) is the type of work to be taken.

All four domains have integration in the adjacent domain. So that sub-divisions appear, namely Andragogy Content Knowledge (ACK), Technology Andragogy Knowledge (TAK), Work Technology Knowledge (TWK), and Work Content Knowledge (WCK). In facilitating the correlation between domains and subdomains, researchers explain in the formation of four circles that symbolize dominance and mutual integration. This is limited to describing relationships, but not to explain the strength or main influence of the relationship (Figure 2). The following descriptions of domains and subdomains are detailed (Table 2).

Table 2. Identity, domain and description of the conceptual framework of knowledge in vocational education

\begin{tabular}{|c|c|c|c|}
\hline Identity & Domain/sub domain & Description & References \\
\hline (TK) & $\begin{array}{l}\text { Technology } \\
\text { Knowledge }\end{array}$ & $\begin{array}{l}\text { The subject matter of knowledge sourced from the } \\
\text { educational curriculum into subjects and subject } \\
\text { matter content. Vocational education is divided } \\
\text { into three groups of subjects, namely normative, } \\
\text { adaptive and productive. Everything must have } \\
\text { content in scrutiny in the field of expertise. }\end{array}$ & \\
\hline$(\mathrm{AK})$ & $\begin{array}{l}\text { Andragogy } \\
\text { Knowledge }\end{array}$ & $\begin{array}{l}\text { The ability to manage learning in theory and } \\
\text { practice-oriented to maturity and independence. } \\
\text { This is relevant to } 21 \text { st-century learning. }\end{array}$ & \\
\hline (CK) & Content Knowledge & $\begin{array}{l}\text { The knowledge about how to use technology in } \\
\text { learning needs in theory and practice. In } \\
\text { vocational education tools based technology in } \\
\text { the discussion of this domain. }\end{array}$ & \\
\hline$(\mathrm{WK})$ & Work Knowledge & $\begin{array}{l}\text { The knowledge of what work is needed and what } \\
\text { competencies are needed. The teacher's } \\
\text { experience in the job is a determinant of success } \\
\text { to be transferred to students. }\end{array}$ & {$[35,41-47]$} \\
\hline (ACK) & $\begin{array}{l}\text { Andragogy Content } \\
\text { Knowledge }\end{array}$ & $\begin{array}{l}\text { The knowledge about how to represent and } \\
\text { formulate the subject easily understood by } \\
\text { students. Models, methods, strategies, and } \\
\text { techniques become ways of packaging learning. }\end{array}$ & \\
\hline (TAK) & $\begin{array}{l}\text { Technology } \\
\text { Andragogy } \\
\text { Knowledge }\end{array}$ & $\begin{array}{l}\text { The knowledge about technology that can help } \\
\text { andragogy such as investigations or inventions in } \\
\text { the construction of vocational knowledge. }\end{array}$ & \\
\hline (TWK) & $\begin{array}{l}\text { Technology Work } \\
\text { Knowledge }\end{array}$ & $\begin{array}{l}\text { The knowledge about how technology in the } \\
\text { workplace is packaged in learning and support } \\
\text { knowledge construction. }\end{array}$ & \\
\hline (WCK) & $\begin{array}{c}\text { Technology Work } \\
\text { Knowledge }\end{array}$ & $\begin{array}{l}\text { The knowledge about how to work content can be } \\
\text { constructed. }\end{array}$ & \\
\hline
\end{tabular}

The results of the research in the form of conceptual transformation of TPACK to TAWOCK are illustrated in the relationship of Figure 2. There are three concepts, namely (a) the original concept, divided into (a.1) [48, 49] and (a.2) [36, 50-52]; (b) the concept of deformation/deformed concepts [36, 43, 45]; and (c) the additional concept/the concepts raised [50, 52-54]. The whole concept is intended so that the basic elements do not change with the consideration that this concept is in line with the demands of 21 st century learning, namely the content of technology and knowledge. The concept of deformation is a shift in approach from pedagogy to andragogy which is adapted to the concept of learning in vocational education. Additional concepts are important because vocational specific values indicate that each competency is not the same among fields. This is what distinguishes general concepts from vocational concepts. So, The TAWOCK conceptual model in Figure 3, becomes a new concept offered on the concept of knowledge in the field of vocational education. 


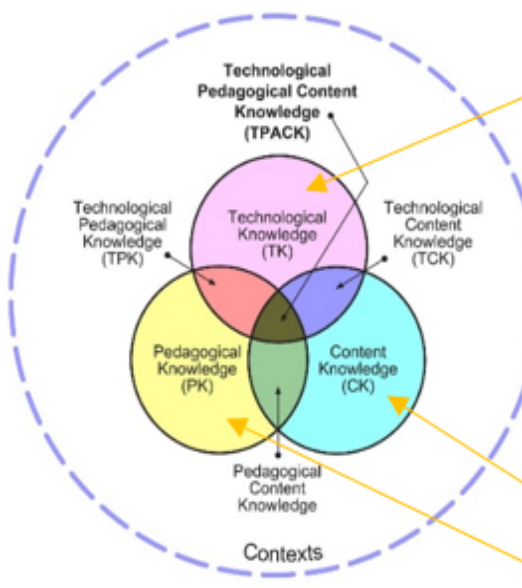

Fig. (a) (a.1)

$[48,49]$

(c)

$[50,52-54]$

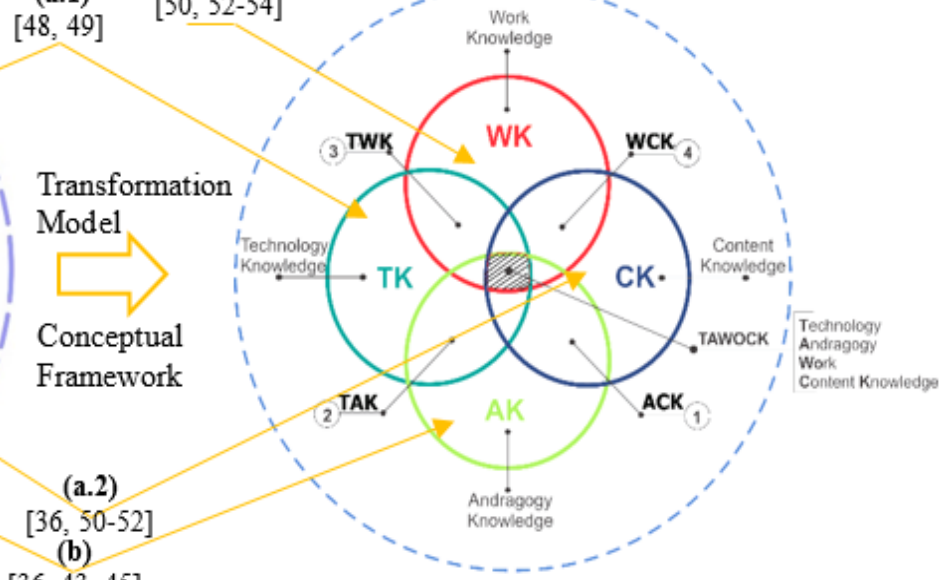

$[36,43,45]$

Fig. (b)

Figure 3. (a) Conceptual framework TPACK http://tpack.org/ and

(b) Conceptual framework TAWOCK for vocational education [54]

\section{CONCLUSION}

The essence of this research is how the conceptual framework in vocational learning is appropriate and specific. This research links several theoretical studies relating to knowledge of content, knowledge of technology, knowledge of learning approaches, and knowledge of integrated vocational education goals. Four domains as the key in applying vocational knowledge are Technology, Andragogy, Employment, and Content Knowledge. Characteristics are built from TPACK with several intact, flawed, and raised concepts. Each component is supported by relevant sources. Conceptual findings can be applied in the vocational field in terms of subject matter, strategic instructional representation, student learning and conception, general pedagogy, curriculum and media, context, objectives, and assessment. The TAWOCK conceptual model is set theoretically and empirical results as initial learning. Therefore, the conceptual model of the TAWOCK framework for the vocational field needs to be tested.

\section{REFERENCES}

[1] A. Hakim, "Contribution of Competence Teacher (Pedagogical, Personality, Professional Competence and Social) On the Performance of Learning," The International Journal of Engineering and Science (IJES), vol. 4, no. 2, pp. 1-12, 2015.

[2] A. P. Sasmito, D. Kustono, and H. Elmunsyah, "Conceptual model for improving quality of teacher in Indonesian vocational school," Int. J. Eval. \& Res Educ., vol. 9, no. 1, pp. 34-44, 2020.

[3] J. Juhji and P. Nuangchalerm, "Interaction between Scientific Attitudes and Science Process Skills Toward Technological Pedagogical Content Knowledge," Journal for the education of gifted young scientists, vol. 8, no. 1, pp. 1-16, 2020.

[4] E. Lee, M. N. Brown, J. A. Luft, and G. H. Roehrig, “Assessing Beginning Secondary Science Teachers' PCK: Pilot Year Results," School Science and Mathematics, vol. 107, no. 2, pp. 52-60, 2007.

[5] L. Shulman, "Knowledge and Teaching: Foundations of the New Reform," Harvard Educational Review, vol. 57, no. 1, pp. 1-23, 1987. [Online]. Available: https://doi.org/10.17763/haer.57.1.j463w79r56455411

[6] P. Tamir, "Subject matter and related pedagogical knowledge in teacher education," Teaching and Teacher Education, vol. 4, no. 2, pp. 99-110, 1988.

[7] J. Loughran, P. Mulhall, and A. Berry, "In search of pedagogical content knowledge in science: Developing ways of articulating and documenting professional practice," J. Res. Sci. Teach., vol. 41, no. 4, pp. 370-391, 2004.

[8] Z. Deng, "Pedagogical content knowledge reconceived: Bringing curriculum thinking into the conversation on teachers' content knowledge," Teaching and Teacher Education, vol. 72, pp. 155-164, May 2018.

[9] N. Meschede, A. Fiebranz, K. Möller, and M. Steffensky, "Teachers' professional vision, pedagogical content knowledge and beliefs: On its relation and differences between pre-service and in-service teachers," Teaching and Teacher Education, vol. 66, pp. 158-170, Aug 2017.

[10] S. Ramadhan, et al., "The Development of an Instrument to Measure the Higher Order Thinking Skill in Physics," European J Ed Res, vol. 8, no. 3, pp.743-751, Jul 2019.

[11] M. J. Koehler, P. Mishra, K. Kereluik, T. S. Shin, and C. R. Graham, "The Technological Pedagogical Content Knowledge Framework," in Handbook of Research on Educational Communications and Technology, J. M. Spector, M. D. Merrill, J. Elen, and M. J. Bishop, Eds. New York, NY: Springer New York, pp. 101-111, 2014. 
[12] P. Mishra and M. J. Koehler, "Technological Pedagogical Content Knowledge: A Framework for Teacher Knowledge," Teachers College Rec, vol. 108, no. 6, pp. 1017-1054, Jun 2006.

[13] H. E. Alharbi, "An Arabic assessment tool to measure Technological Pedagogical and Content Knowledge," Computers \& Education, vol. 142, pp. 1-12, Dec 2019.

[14] J. K. Suh and S. Park, "Exploring the relationship between pedagogical content knowledge (PCK) and sustainability of an innovative science teaching approach," Teaching and Teacher Education, vol. 64, pp. 246-259, May 2017.

[15] M. B. Uçar, C. Demir, and E. Hiğde, "Exploring the Self-confidence of Preservice Science and Physics Teachers towards Technological Pedagogical Content Knowledge," Procedia - Social and Behavioral Sciences, vol. 116, pp. 3381-3384, Feb 2014.

[16] F. F. Hidayah, M. Imaduddin, D. Praptaningrum, and D. Ristanti, "Cogenerative Dialogue of Cross-Generation Educators to Improve Chemistry Teaching Quality through Technology," Journal for the Education of Gifted Young Scientists, vol. 8, no. 1, pp. 465-487, Mar 2020.

[17] M. Zayyadi, et al., "Content and Pedagogical Knowledge of Prospective Teachers in Mathematics Learning: Commognitive Framework," Journal for the Education of Gifted Young Scientists, vol. 8, no. 1, pp. 515-532, 2020.

[18] A. Tanak, "Designing TPACK-based course for preparing student teachers to teach science with technological pedagogical content knowledge," Kasetsart Journal of Social Sciences, vol. 41, no. 1, p. S2452315118301000, Aug 2018. [Online]. Available: https://so04.tci-thaijo.org/index.php/kjss/article/view/229145

[19] T.-H. Jen, Y.-F. Yeh, Y.-S. Hsu, H.-K. Wu, and K.-M. Chen, "Science teachers' TPACK-Practical: Standard-setting using an evidence-based approach," Computers \& Education, vol. 95, pp. 45-62, Apr 2016.

[20] B. Trilling and C. Fadel, 21st century skills: Learning for life in our times. Jossey-Bass, 2009.

[21] S. Hof and M. Strupler Leiser, "Teaching in vocational education as a second career," Empirical Res Voc Ed Train, vol. 6, no. 8, 2014. [Online]. Available: https://link.springer.com/article/10.1186/s40461-014-0008-y

[22] C. Schellenberg, A. Krauss, A. Hättich, and K. Häfeli, "Occupational career patterns over 30 years: Predictors and outcomes," in Empirical Research in Vocational Education and Training, vol. 8, no. 15, 2016.

[23] M. Nurtanto, P. Pardjono, Widarto, and S. D. Ramdani, "The Effect of STEM-EDP in Professional Learning on Automotive Engineering Competence in Vocational High School," Journal for the Education of Gifted Young Scientists, vol. 8, no. 2, Art. no. 2, Jun 2020.

[24] A. Y. Abu Bakar, "Profiling of Aspiration and interest towards STEM and TVET Careers among lower secondary students: A Malaysian case study," Journal for the Education of Gifted Young Scientists, vol. 8, no. 1, pp. 489-500, Mar 2020.

[25] Y. Hendawati, S. Pratomo, S. Suhaedah, N. A. Lestari, T. Ridwan, and N. W. A. Majid, "Contextual teaching and learning of physics at elementary school," J. Phys.: Conf. Ser., vol. 1318, p. 012130, Oct 2019.

[26] M. Nurtanto, D. Widjanarko, H. Sofyan, R. Rabiman, and M. B. Triyono, "Learning by creating: Transforming automotive electrical textual material into visual animation as a creative learning products (clp)," International Journal of Scientific and Technology Research, vol. 8, no. 10, pp. 1634-1642, 2019.

[27] J. H. Chua and H. Jamil, "Factors Influencing the Technological Pedagogical Content Knowledge (TPACK) among TVET instructors in Malaysian TVET Institution," Procedia - Social and Behavioral Sciences, vol. 69, pp. 1539-1547, Dec 2012.

[28] H. Guthrie, R. Harris, M. Simons, and T. Karmel, "Teaching for Technical and Vocational Education and Training (TVET)," in International Handbook of Research on Teachers and Teaching, vol. 21, L. J. Saha and A. G. Dworkin, Eds. Boston, MA: Springer US, pp. 851-863, 2009.

[29] A. P. Francis, "Why do Some Teachers Trust Digital Technologies and Others Don't?" Michigan State University, ProQuest Dissertations Publishing, 2010. [Online]. Available: https://search.proquest.com/docview/816026428

[30] W. Roel J., Design Science Methodology for Information Systems and Software Engineering. Springer-Verlag Berlin Heidelberg, 2014.

[31] J. W. Rojewski, "A Conceptual Framework for Technical and Vocational Education and Training," in International Handbook of Education for the Changing World of Work, R. Maclean and D. Wilson, Eds. Dordrecht: Springer Netherlands, pp. 19-39, 2009.

[32] M. Pavlova, TVET as an important factor in country's economic development, Suppl 1:K3., vol. 3. SpringerPlus, 2014.

[33] M. Pavlova, Technology and Vocational Education for Sustainable Development - Empowering Individuals for the Future. Springer Netherlands, 2009.

[34] S. Billett, Vocational Education - Purposes, Traditions and Prospects. Springer Netherlands, 2011.

[35] P. Sudira, TVET Abad XXI: Filosofi, Teori, dan Strategi Pembelajaran Vokasional. UNY Press, 2017.

[36] V. X. Wang, Vocational Education Technologies and Advances in Adult Learning: New Concepts. IGI Global. 2012.

[37] L. M. Blaschke, "Heutagogy and Lifelong Learning: A Review of Heutagogical Practice and Self-Determined Learning," The International Review of Research in Open and Distributed Learning, vol. 13, no. 1, pp. 56-71, 2012.

[38] N. W. A. Majid, S. Fuada, M. K. Fajri, M. Nurtanto, and R. Akbar, "Progress Report of Cyber Society v1.0 Development as A Learning Media for Indonesian Society to Support EFA," International Journal of Engineering Pedagogy, vol. 10, no. 4, 2020. [Online]. Available: https://online-journals.org/index.php/i-jep/article/view/13085

[39] Z. Arifin, M. Nurtanto, A. Priatna, N. Kholifah, and M. Fawaid, "Technology Andragogy Work Content Knowledge Model as a New Framework in Vocational Education: Revised Technology Pedagogy Content Knowledge Model," TEM Journal, vol. 9, no. 2, pp. 786-791, 2020. 
[40] M. Nurtanto, Z. Arifin, H. Sofyan, W. Warju, and S. Nurhaji, "Development of Model for Professional Competency Assessment (PCA) in Vocational Education: Study of the Engine Tune-Up Injection System Assessment Scheme," Journal of Technical Education and Training, vol. 12, no. 2, pp. 34-45, Feb 2020.

[41] C. Kuhn, A. C. Alonzo, and O. Zlatkin-Troitschanskaia, "Evaluating the pedagogical content knowledge of pre- and in-service teachers of business and economics to ensure quality of classroom practice in vocational education and training," Empir. Res. Vocat. Educ. Train, vol. 8, no. 5, 2016.

[42] A.-M. Bathmaker, "Defining "knowledge" in vocational education qualifications in England: an analysis of key stakeholders and their constructions of knowledge, purposes and content," Journal of Vocational Education \& Training, vol. 65, no. 1, pp. 87-107, Mar 2013.

[43] S. Choy and B. Delahaye, “Andragogy in Vocational Education and Training: Learners' perspective,” Proceedings 5th Annual Conference off the Australian VET Research Association (AVETRA), Melbourne, Australia, 2002. [Online]. Available: https://core.ac.uk/reader/10877558

[44] A. Muduli, V. Kaura, and A. Quazi, "Pedagogy or andragogy? Views of Indian postgraduate business students," IIMB Management Review, vol. 30, no. 2, pp. 168-178, Jun 2018.

[45] S. Loeng, "Various ways of understanding the concept of andragogy," Cogent Education, vol. 5, no. 1, Jan 2018. [Online]. Available: https://doi.org/10.1080/2331186X.2018.1496643

[46] N. Boreham, "Control and The Work-Based Route to Vocational Qualifications," British Journal of Educational Studies, vol. 50, no. 2, pp. 225-237, 2002.

[47] T. Scheib, "Work Process Knowledge," in Zülch G., Jagdev H.S., Stock P. (eds). Integrating Human Aspects in Production Management. IFIP International Conference for Information Processing, vol 160. Springer, Boston, MA., 2005. [Online]. Available: https://link.springer.com/chapter/10.1007\%2F0-387-23078-5_17

[48] A. Lytvyn, et al., "Informatization of technical vocational schools: Theoretical foundations and practical approaches," Educ Inf Technol, vol. 25, no. 1, pp. 583-609, Jan 2020.

[49] Q. Yue, "Reasonable Application of Information Technology in Vocational Education," The 2015 1st International Conference on Information Technologies in Education and Learning (ICMII 2015), Hangzhou, China, 2016. [Online]. Available: https://doi.org/10.2991/icitel-15.2016.15

[50] M. Fjellström, "Vocational education in practice: a study of work-based learning in a construction programme at a Swedish upper secondary school," Empir. Res. Vocat. Educ. Train, vol. 6, no. 2, 2014. [Online]. Available: https://doi.org/10.1186/1877-6345-6-2

[51] M. Koopman, P. Teune, and D. Beijaard, "Development of student knowledge in competence-based pre-vocational secondary education," Learning Environ Res, vol. 14, no. 3, pp. 205-227, Oct 2011.

[52] F. Rauner and R. Maclean, Handbook of Technical and Vocational Education and Training Research. Springer Netherlands, 2008

[53] G. Spöttl, S. Schulte, and T. Grantz, "Work Place Oriented Learning With Digital Media Consequences for Competency Development," US-China Education Review, A9, pp. 769-775, 2012, [Online]. Available: https://files.eric.ed.gov/fulltext/ED537175.pdf

[54] H. Rintala and P. Nokelainen, "Vocational Education and Learners' Experienced Workplace Curriculum," Vocat. Learn, vol. 13, no. April, pp. 113-130, 2019. 